\title{
Pengembangan Game Edukasi dengan Konteks Kearifan Lokal Banten pada Materi Matriks
}

\author{
Arum Widya Safitri ${ }^{1 *}$, Heni Pujiastuti², Ria Sudiana ${ }^{3}$ \\ 1,2,3 Universitas Sultan Ageng Tirtayasa \\ *arumws29@gmail.com
}

Diterima: Mei 2020. Disetujui: Juni 2020. Dipublikasikan: Juli 2020.

\begin{abstract}
ABSTRAK
Tujuan penelitian adalah menghasilkan produk game edukasi matematika sebagai media pembelajaran matematika dengan konteks kearifan lokalBanten yanglayak, efektif serta praktis dan dapat digunakan dilapangan. Penelitian pengembangan ini dilakukan dengan mengadopsi model pengembangan ADDIE yang terdiri dari lima tahap yaitu analyze (analisis), design (perancangan), development (pengembangan), implementation (implementasi), serta evaluation (evaluasi). Instrumen yang digunakan yaitu lembar angket validasi ahli, lembar angket respons guru matematika dan siswa, serta lembar ketuntasan level game. Adapun hasil yang diperoleh yaitu bahwa game edukasi layak, praktis, dan efektif digunakan pada kegiatan pembelajaran.

Kata kunci: game edukasi, matriks, kearifan lokal.
\end{abstract}

\begin{abstract}
The research objective is to produce educational math games as a medium of learning mathematics with the context of local wisdom Banten that meets valid, effective and practical criteria and can be used in the field. Research and development is done by adopting the development model of ADDIE which consists of five stages: analyze, design, development, implementation, and evaluation. The instrument used in this research are questionnaire of validation experts, questionnaire responses of mathematics teachers and students, as well as the mastery level of the game. The results obtained that the game is feasible, practical, and effective to use in learning activities.

Keywords: educational game, matrix, local wisdom.
\end{abstract}

How to Cite: Safitri, A.W., Pujiastuti, H., \& Sudiana, R. (2020). Pengembangan Game Edukasi dengan Konteks Kearifan Lokal Banten pada Materi Matriks. Journal of Medives: Journal of Mathematics Education IKIP Veteran Semarang, 4(2), 319-328. 


\section{PENDAHULUAN}

Matematika salah satu mata pelajaran yang dianggap sulit oleh siswa karena siswa hanya mampu menerima materi, mereka tidak mampu mengaitkan materi sebelumnya dengan materi yang dipelajari atau mengaitkan konsep sebelumnya dengan konsep yang dipelajari (Kusmanto \& Marliyana, 2014). Materi matematika yang dianggap sulit oleh siswa adalah matriks karena siswa mengalami kesulitan sehingga siswa selalu melakukan beberapa kesalahan yaitu kurangnya pemahaman konsep operasi hitung matriks, kesalahan siswa yang lupa tanda kurung siku, miskonsep-si tentang bilangan penjumlahan dan pengurangan matriks jika ada tanda negatif (Naila et al., 2018). Maka hal tersebut perlu sebuah inovasi media pembelajaran yang mampu memberikan pengalaman belajar yang lebih seru dan menyenangkan salah satunya dengan membuat media pembelajaran yaitu game edukasi.

Melalui pembelajaran berbasis game, guru mampu memberikan pening-katan terhadap kualitas dalam pengajar-an serta mampu mempersiapkan para siswa dalam berpikir kritis serta peme-cahan masalah atau problem solving (Chen \& Wang, 2009; Schilling, 2009).

Game pada umumnya merupakan suatu media hiburan yang dimainkan oleh berbagai kalangan sebagai penghilang dari rasa jenuh serta mampu menciptakan kesenangan dalam diri manusia. Menurut Adams, game umumnya memiliki beberapa manfaat seperti melatih pemecahan masalah, pengem- bangan otak, melatih kecepatan, mening-katkan konsentrasi, dan lainnya. Terda-pat beberapa jenis dalam sebuah game seperti jenis action, strategy, role play-ing, sport, vehicle simulations, construc-tion and management simulations, adventure, artificial life and puzzle games (Kurniati, Tanzil, \& Purnomo, 2015).

Siswa SMA merupakan kategori remaja, kategori tersebut mereka masih cenderung menyukai kegiatan bermain baik berbentuk permainan tradisional maupun game online serta game offline yang sekarang sangat diminati oleh kalangan siswa-siswa SMP dan SMA. Hal ini didukung dari penelitian Sari, dkk (2014) bahwa para pemain game rata-rata memiliki usia dari 12-30 tahun dengan persentase $80 \%$, usia 12 sampai 21 tahun merupakan usia remaja. Dari hasil survei tersebut diketahui bahwa siswa SMA merupakan salah satu dalam kategori usia remaja yang sangat menyukai kegiatan bermain sebuah game komputer. Mereka mampu menghabiskan waktu beberapa jam lamanya di depan layar komputer hanya karena ingin menyelesaikan misi dalam sebuah game (Sari, Saputro, \& Hastuti, 2014). Berdasarkan pemaparan tersebut, peneliti memfokuskan penelitian tersebut kepada siswa SMA. Berdasarkan hasil suatu survey yaitu Agate Studio diperoleh $46 \%$ atau 552 pemain memilih game berjenis Role Playing Game (RPG) sebagai game paling favorit saat ini (Kurniati et al., 2015).

Sebuah media tidak hanya menyampaikan suatu konten saja namun memberikan beberapa konten yang mampu bermanfaat, salah satunya 
memperkenalkan konteks kearifan lokal yaitu kearifan lokal Banten. Saat ini remaja lebih menyukai keberadaan budaya luar negeri dibandingkan dengan budaya lokal dalam negeri sendiri. Hal ini terlihat dari mulai munculnya fenomena remaja yang kehilangan pemahaman mengenai asas tata krama dan lebih mengedepankan sikap individual. Selanjutnya para remaja saat ini sudah mulai menyukai gaya hidup yang hedonisme dan lebih menyukai gaya hidup yang cenderung glamour (Abdallah \& Parama, 2016).

Pengembangan sebuah media pembelajaran yang baik tidak hanya menyampaikan suatu tujuan saja akan tetapi dapat memberikan nilai karakter kepada siswa-siswi agar senantiasa mampu menciptakan karakter yang tidak keluar dari jalur karakter budaya. Pengetahuan kearifan lokal yang dikemukakan salah satunya yaitu sebanyak $77,5 \%$ masyarakat menyatakan tidak mengetahui kearifan lokal kesehatan atau tradisi pengobatan dari pemanfaatan pohon terep di Baduy dan sebanyak $84,5 \%$ masyarakat tidak mengetahui kearifan lokal kuliner yaitu jojorong makanan khas suku Baduy (Armananti, 2018).

Kearifan lokal yang digunakan dalam pembelajaran dapat berbentuk nilai atau kearifan lokal dalam bentuk bukan nilai (Kharis A, 2017). Kearifan berbentuk nilai misalnya nilai keagamaan yang sangat kental di daerah Banten dengan banyaknya tempat untuk ziarah, diharapkan siswa menjadi lebih religious dengan menghayati dan mencintai agama yang dianutnya. Hal ini sesuai dengan kompetensi inti yang diharapkan oleh kurikulum 2013. Sedangkan kearifan lokal berbentuk bukan nilai yang dimasukkan dalam pembelajaran, misalnya melalui bangunan-bangunan bersejarah, budaya khas daerah, dan potensi-potensi yang terdapat dalam suatu daerah, akan menambah rasa cinta kepada daerah dan potensi kelokalan siswa akan tetap kukuh terjaga di tengahtengah derasnya arus globalisasi (Nurafni, Pujiastuti, \& Mutaqin, 2020). Hal ini diperlukan suatu media yang bertujuan untuk melestarikan kearifan lokal kepada generasi milenial dan generasi masa yang akan datang.

Berdasarkan uraian yang telah dipaparkan, maka peneliti tertarik melaksanakan penelitian mengenai media pembelajaran berupa game edukasi dengan konteks kearifan lokal yaitu Banten. Hal ini didukung oleh sebuah penelitian oleh Pramuditya \& Noto (2018), mengenai "Desain Game Edukasi Berbasis Android pada Materi Logika Matematika" didapatkan 93,76\% game edukasi valid serta praktis dengan ditinjau dari persentase penilaian bebera-pa siswa yaitu siswa dengan tingkatan kemampuan tinggi sebesar 94,8\%, siswa dengan tingkatan kemampuan sedang se-besar 94,2\%, dan siswa dengan tingkatan kemampuan rendah sebesar 92,2\%.

Rumusan masalah dalam penelitian ini yaitu bagaimana mengembangkan game edukasi serta kelayakan, kepraktis-an, dan keefektifan dengan konteks kearifan lokal Banten pada materi matriks. Tujuan dalam penelitian yaitu untuk mengetahui cara mengembangkan game edukasi serta 
menghasilkan produk yang layak, praktis dan efektif dapat digunakan oleh masyarakat khususnya siswa SMA/sederajat. Dalam penelitian ini memuat beberapa manfaat yaitu sebagai inovasi pembelajaran bagi guru maupun sebagai media pembelajar-an mandiri bagi siswa yang diharapkan mampu memperkenalkan kearifan lokal dari Banten baik berupa nilai-nilai maupun budaya serta sebagai bahan untuk penelitian selanjutnya.

\section{METODE PENELITIAN}

Penelitian ini merupakan

Research \& Development (R\&D) dengan model pengembangan yaitu model pengem-bangan ADDIE (Analyze, Design, De-velopment, Implementation, Evaluation). Model ini memiliki lima langkah atau tahapan yang mudah dipahami dan mampu diimplementasikan dalam melaksanakan pengembangan dan menghasilkan suatu produk pengembangan seperti buku ajar, modul pembelajaran, video pembelajaran, multimedia, dan lain-lain (Tegeh Jampel, \& Pudjawan, 2014). Penelitian dilaksanakan pada salah satu SMA yang ada di Kabupaten Tangerang kepada siswa kelas XI menggunakan angket dan tes ketuntasan level game di bulan Februari 2020. Adapun tahap ADDIE yang dilakukan sebagai berikut.

\section{Analyze (Analisis)}

Pada tahap ini dilaksanakan kegiatan analisis baik analisis kinerja maupun analisis kebutuhan. Pada analisis kinerja secara umum mengenai pengkajian studi pustaka untuk mengetahui permasalahan yang terjadi dan menemukan solusi. Analisis kebutuhan pada penelitian ini melaksanakan kegiatan pengkajian terkait kebutuhan baik untuk mengembangkan game edukasi serta kebutuhan uji coba kepada siswa.

\section{Design (Perancangan)}

Tahap selanjutnya adalah membuat rancangan pada game edukasi yang akan dikembangkan baik untuk pembuatan map, karakter, level game, materi dan soal, event, quest, dan flowchart untuk game itu sendiri. Flowchart berfungsi sebagai format dari awal sampai akhir pada game yang akan dikembangkan.

\section{Development (Pengembangan)}

Tahap selanjutnya yaitu peneliti menghasilkan produk awal yang selanjutnya divalidasi oleh para ahli. Kegiatan ini bertujuan untuk mendapatkan produk yang dapat dijadikan uji coba pada saat tahap implementasi. Adapun penjabaran beberapa kegiatan pada tahap ini sebagai berikut.

\section{Validasi terkait Instrumen}

Instrumen yang sebelumnya telah dibuat divalidasi dahulu agar memperoleh alat pengukuran game edukasi yang dikembangkan.

\section{Validasi terkait Produk}

Produk awal yang telah dikembangkan kemudian dilakukan uji validasi media yang bertujuan untuk mengetahui kelayakan media yaitu game edukasi. Game edukasi diuji validasi melalui 2 jenis ahli yaitu ahli media serta ahli materi. Para ahli yang 
menjadi validator game edukasi merupakan dosen pendi-dikan matematika di Universitas Sultan Ageng Tirtayasa dan juga dosen diluar Universitas Sultan Ageng Tirtayasa. Pada tahap ini diperoleh penilaian dari validator dan juga persentase validasi yang diberikan oleh validator.

\section{Implementation (Implementasi)}

Pada tahap ini peneliti melaksanakan hasil penilaian validator sebagai perbaikan game edukasi agar relevan dan memenuhi kegiatan pembelajaran baik untuk guru maupun siswa. Pada tahap implementasi peneliti melaksanakan uji coba baik kepada guru matematika maupun kepada siswa. penelitian ini berawal memperoleh hasil respons guru matematika untuk mengetahui kepraktis-an produk. Lalu dilanjutkan memperoleh hasil respons siswa serta hasil ketuntasan level game untuk mengetahui keefek-tifan produk.

\section{Evaluation (Evaluasi)}

Setelah tahap implementasi dilaksanakan tahap evaluasi yang bertujuan untuk menentukan kelayakan produk yang dikembangkan. Hasil validasi ahli serta uji coba di lapangan dianalisis dengan menghitung persentase baik persentase kelayakan, kepraktisan, keefektifan (\%) skor yang didapatkan dari kegiatan sebelumnya berdasarkan beberapa kriteria pada Tabel 1.

Tabel 1. Kriteria Persentase Skor Seluruh Ahli

\begin{tabular}{cc}
\hline Persentase & Kriteria \\
\hline $80 \%<\mathrm{P} \leq 100 \%$ & Sangat Valid \\
$60 \%<\mathrm{P} \leq 80 \%$ & Valid \\
$40 \%<\mathrm{P} \leq 60 \%$ & Cukup Valid \\
$20 \%<\mathrm{P} \leq 40 \%$ & Tidak Valid \\
\hline
\end{tabular}

$\frac{0 \%<\mathrm{P} \leq 20 \% \quad \text { Sangat Tidak Valid }}{(\text { Diadaptasi dari Fithriyah \& As'ari (2012)) }}$

Tabel 2. Kriteria Penilaian Seluruh Ahli

\begin{tabular}{cc}
\hline Nilai & Kategori \\
\hline A & Dapat digunakan tanpa revisi \\
B & Dapat digunakan sedikit revisi \\
C & Dapat digunakan banyak revisi \\
D & Tidak dapat digunakan
\end{tabular}
(Diadaptasi dari Yamasari (2010))

Tabel 3. Kriteria Persentase Skor Angket Respons

\begin{tabular}{cc}
\hline Persentase & Kriteria \\
\hline $80 \% \leq P R \leq 100 \%$ & Sangat Baik \\
$60 \% \leq P R \leq 80 \%$ & Baik \\
$40 \% \leq P R \leq 60 \%$ & Cukup Baik \\
$20 \% \leq P R \leq 40 \%$ & Tidak Baik \\
$0 \% \leq P R \leq 20 \%$ & Sangat Tidak Baik \\
\hline & (Diadaptasi dari Wicaksono (2014))
\end{tabular}

Tabel 4. Kriteria Persentase Siswa Tuntas

\begin{tabular}{cc}
\hline Persentase & Kriteria \\
\hline $80 \% \leq P S T \leq 100 \%$ & Sangat Baik \\
$60 \% \leq P S T \leq 80 \%$ & Baik \\
$40 \% \leq P S T \leq 60 \%$ & Cukup Baik \\
$20 \% \leq P S T \leq 40 \%$ & Tidak Baik \\
$0 \% \leq P S T \leq 20 \%$ & Sangat Tidak Baik \\
\hline \multicolumn{2}{r}{ (Widyoko (2009) dengan dimodifikasi) }
\end{tabular}

\section{HASIL DAN PEMBAHASAN}

Tahapan yang dilaksanakan dalam penelitian ini terdiri atas analisis, analisis yang dilakukan untuk meninjau perma-salahan dalam pengembangan media. Desain atau perancangan adalah mem-buat rancangan untuk produk yang dikembangkan. Tahap pengembangan, menghasilkan produk awal berdasarkan masukan dari para ahli yaitu 3 orang ahli media serta 3 orang ahli materi, serta diujicobakan kepada guru dan siswa melalui angket respon.

\section{Penilaian para Ahli}

Penilaian para ahli ditujukan untuk meninjau kelayakan game edukasi. Penilaian para ahli terdiri atas 
3 orang ahli media serta 3 orang ahli materi. Hasil penilaian para ahli terkait pengembangan game edukasi dengan konteks kearifan lokal Banten dinyatakan layak digunakan. Adapun hasil penilaian para ahli yang diperoleh sebagai berikut.

Tabel 5. Hasil Penilaian Para Ahli Materi

\begin{tabular}{lcccc}
\hline \multicolumn{1}{c}{ Aspek } & Total Skor & Pernyataan & Presentase Total & Kriteria \\
\hline Kualitas Isi dan Tujuan Pembelajaran & 195 & 15 & $87,9 \%$ & Sangat Valid \\
Kualitas Instruksional & 116 & 10 & $82,2 \%$ & Sangat Valid \\
\hline
\end{tabular}

Tabel 6. Hasil Penilaian Para Ahli Media

\begin{tabular}{ccccc}
\hline Aspek & Total Skor & Pernyataan & Presentase Total & Kriteria \\
\hline Kualitas Teknis & 288 & 22 & $85,8 \%$ & Sangat Valid \\
\hline
\end{tabular}

Tabel 7. Hasil Penilaian Seluruh Para Ahli

\begin{tabular}{cccc}
\hline Ahli & Total Skor & Presentase Total & Kriteria \\
\hline Ahli Materi & 311 & $85,30 \%$ & Sangat Valid \\
Ahli Media & 288 & & \\
\hline
\end{tabular}

Tabel 8. Hasil Kriteria Penilaian Seluruh Para Ahli

\begin{tabular}{cc}
\hline Ahli & Kriteria Penilaian \\
\hline Ahli Materi & B \\
Ahli Media & B \\
\hline
\end{tabular}

Pada penilaian para ahli materi diperoleh persentase yaitu $87,9 \%$ pada aspek kualitas isi dan tujuan pembelajar-an, lalu diperoleh juga persentase yaitu $82,2 \%$ pada aspek kualitas instruksional. Dari perolehan persentase tersebut bahwa game edukasi dengan konteks kearifan lokal Banten sangat layak digunakan dalam pembelajaran.

Pada penilaian para ahli media diperoleh persentase yaitu $85,8 \%$ pada aspek kualitas teknis. Dari perolehan hasil tersebut bahwa game edukasi dengan konteks kearifan lokal Banten sangat layak. Dari seluruh penilaian para ahli baik ahli media maupun ahli materi dipaparkan pada Tabel 7.

Penilaian dari seluruh para ahli baik ahli media maupun ahli materi diperoleh yaitu $85,30 \%$ dengan total skor dari ahli materi yaitu 311 dan ahli media yaitu 288. Berdasarkan perolehan hasil tersebut dapat dinyatakan bahwa game edukasi dengan konteks kearifan lokal Banten layak digunakan dalam pembela-jaran.

Penilaian para ahli memberikan kategori kriteria dengan nilai B yang berarti dapat digunakan dengan sedikit revisi.

\section{Respons Guru Matematika}

Setelah game edukasi divalidasi para ahli dan direvisi sesuai dengan beberapa saran dari para ahli, kemudian produk diujicoba terlebih dahulu pada tiga orang guru matematika, untuk mengetahui respons guru matematika terhadap kepraktisan produk. Adapun hasil yang diperoleh dapat dilihat pada Tabel 9.

Pada hasil dari respons guru matematika diperoleh persentase yaitu 
Tabel 9. Hasil Respons Para Guru Matematika pada Setiap Aspek

\begin{tabular}{cccc}
\hline Aspek & Pernyataan & Presentase & Kriteria \\
\hline Kualitas Isi dan Tujuan Pembelajaran & 15 & $84,6 \%$ & Sangat Baik \\
Kualitas Instruksional & 9 & $78,1 \%$ & Baik \\
Kualitas Teknis & 22 & $84,5 \%$ & Sangat Baik \\
\hline
\end{tabular}

Tabel 10. Hasil Respons Seluruh Guru Matematika

\begin{tabular}{cccc}
\hline Responden & Pernyataan & Presentase & Kriteria \\
\hline Guru Matematika & 46 & $82,4 \%$ & Sangat Baik \\
\hline
\end{tabular}

$84,6 \%$ pada aspek kualitas isi dan tujuan pembelajaran dengan respons diperoleh sangat baik, selanjutnya diperoleh persentase yaitu $78,1 \%$ pada aspek kualitas instruksional dengan respons diperoleh baik dan diperoleh persentase yaitu $84,5 \%$ pada aspek kualitas teknis dengan respons diperoleh sangat baik. Berdasarkan Tabel 10 diperoleh bahwa persentase respon seluruh guru mate-matika yaitu $82,4 \%$ dengan respons diperoleh sangat baik. Dan berdasarkan pada Tabel 8 bahwa penilaian para ahli diperoleh nilai $\mathrm{B}$ yang artinya dapat digunakan dengan sedikit revisi. Pada pemaparan hasil tersebut maka dapat dinyatakan bahwa game edukasi dengan konteks kearifan lokal Banten praktis digunakan dalam pembelajaran.

\section{Respons Siswa dan Ketuntasan Level Game}

Setelah melaksanakan uji coba kepada guru matematika, kegiatan selan-jutnya adalah menguji coba game edukasi kepada 15 orang siswa kelas XI. Hal tersebut dilakukan untuk mengeta-hui respons siswa serta ketuntasan siswa terkait keefektifan game edukasi tersebut. Adapun hasil yang dapat diperoleh sebagai berikut.

Pada hasil dari respons siswa diperoleh presentase yaitu 93,3\% pada aspek kualitas isi dan tujuan pembelajar-an dengan respons yang diperoleh sangat baik, lalu diperoleh presentase yaitu $91,1 \%$ pada aspek kualitas instruksional dengan respons yang diperoleh sangat baik, serta diperoleh presentase yaitu 90,9\% pada aspek kualitas teknis dengan respons yang diperoleh sangat baik. Berdasarkan Tabel 12 diperoleh bahwa presentase total respons siswa yaitu 91,33\% dengan total skor 548 dari 40 pernyataan dengan kriteria respons sangat baik serta pada Tabel 13 bahwa

Tabel 11. Hasil Respons Siswa pada Setiap Aspek

\begin{tabular}{lccc}
\hline \multicolumn{1}{c}{ Aspek } & Total Skor & Presentase & Kriteria \\
\hline Kualitas Isi dan Tujuan Pembelajaran & 168 & $93,3 \%$ & Sangat Baik \\
Kualitas Instruksional & 82 & $91,1 \%$ & Sangat Baik \\
Kualitas Teknis & 300 & $90,9 \%$ & Sangat Baik \\
\hline
\end{tabular}

Tabel 12. Hasil Respons Siswa Keseluruhan

\begin{tabular}{cccc}
\hline Responden & Total Skor & Presentase & Kriteria \\
\hline Siswa & 548 & $91,33 \%$ & Sangat Baik \\
\hline
\end{tabular}

Tabel 13. Hasil Ketuntasan Level Game

\begin{tabular}{lcc}
\hline \multicolumn{1}{c}{ Kriteria } & Jumlah & Presentase \\
\hline Siswa yang Tuntas & 15 & $100 \%$ \\
Siswa yang Belum Tuntas & 0 & $0 \%$ \\
\hline
\end{tabular}


hasil ketuntasan siswa pada level game diperoleh persentase $100 \%$ dengan kategori sangat baik. Berdasarkan dari pemaparan hasil tersebut dapat dinyatakan bahwa game edukasi dengan konteks kearifan lokal Banten efektif digunakan dalam pembelajaran.

\section{Evaluasi Produk}

Evaluasi bertujuan untuk memperoleh sebuah produk yang layak digunakan di lapangan. Produk ditinjau kembali berdasarkan hasil penilaian serta saran dari para ahli. Hasil evaluasi dari para ahli dengan sebelumnya diperoleh nilai B yang berarti dapat digunakan dengan sedikit revisi yaitu beberapa kalimat dalam penyampaian materi, pemberian sumber pada gambar yang digunakan, tingkat kesukaran soal, serta desain game edukasi.

Produk final game edukasi ditinjau dari hasil penilaian para ahli yang memperoleh presentase 85,30\% (sangat valid), penilaian para ahli diperoleh nilai B yang berarti dengan sedikit revisi, respons guru matematika memperoleh presentase $82,4 \%$ (sangat baik), respons siswa memperoleh presentase $91,33 \%$ (sangat baik), ketuntasan level game memperoleh siswa yang tuntas dengan presentase 100\%. Dapat disimpulkan game edukasi dengan konteks kearifan lokal Banten telah memenuhi kriteria kelayakan (valid, praktis, efektif) serta dapat digunakan untuk pembelajaran.

\section{PENUTUP}

\section{Berdasarkan penelitian dan
pengembangan yang dilakukan dapat
dinyatakan kesimpulan bahwa game \\ Berdasarkan penelitian dan
pengembangan yang dilakukan dapat
dinyatakan kesimpulan bahwa game \\ Berdasarkan penelitian dan
pengembangan yang dilakukan dapat
dinyatakan kesimpulan bahwa game}

edukasi dengan konteks kearifan lokal Banten dilaksanakan dengan menggunakan tahapan pengembangan yaitu ADDIE. Tahap analisis (analyze) yaitu analisis kebutuhan dan kinerja, tahap perancangan (design) yaitu membuat rancangan game edukasi, tahap pengem-bangan (development) yaitu membuat produk game edukasi awal yang kemudian dinilai oleh para ahli, tahap implementasi (implementation) yaitu game edukasi kemudian diujicobakan kepada guru matematika dan siswa, serta tahap evaluasi (evaluation) yaitu menin-jau penilaian dari seluruh kegiata yang dilakukan baik dari penilaian para ahli maupun respons guru matematika dan siswa serta ketuntasan level game.

Berdasarkan hasil penelitian dan pengembangan yang menghasilkan produk game edukasi diperoleh hasil yang menyimpulkan bahwa game edukasi dengan konteks kearifan lokal Banten pada materi matriks dinyatakan layak, praktis, serta efektif untuk digunakan sebagai media pembelajaran berdasarkan hasil dari penilaian para ahli, respons guru dan siswa, serta hasil ketuntasan level game.

Saran bagi peneliti yang akan mengembangkan game edukasi yang serupa hendaknya perlu ditingkatkan sistematika nyawa dalam game, tampilan soal-soal yang lebih variasi, serta mampu menambahkan pemilihan karakter sesuai keinginan pemain. 


\section{DAFTAR PUSTAKA}

Abdallah, K., \& Parama, P. (2016). Kearifan Lokal Sebagai Benteng Karakter Bangsa: Studi Kasus Tradisi Pernikahan Adat Jawa Ala Kadipaten Pakualaman Yogyakarta. Etnografi, 16(1), 5152.

Armananti, S. H. T. (2018). Pengembangan Game Edukasi Tematik "Eduklok Chemistry" Berbasis Kearifan Lokal Indonesia. Skripsi. Fakultas Sains dan Teknologi. Yogyakarta: Universitas Islam Negeri Sunan Kalijaga.

Chen, M. P., \& Wang, L. C. (2009). The effects of type of interactivity in experiential game-based learning. In M. Chang, R. Kuo, Kinshuk, G.-D. Chen, \& M. Hirose (Ed.), Learning by Playing. Game-based Education System Design and Development. Edutainment 2009. Lecture Notes in Computer Science, vol 5670. Springer, Berlin, Heidelberg.

Fithriyah, I., \& As'ari, AR. (2012). Pengembangan Media Pembelajaran Buku Saku Materi Luas Permukaan Bangun Ruang Untuk Jenjang SMP. Jurnal Matematika. 1 (3) : 1-8.

Granic, I., Lobel, A., \& Engels, R. C. M. E. (2014). The Benefits of Playing Video Games. American Psychologist, 69(1), 66-78.

Kharis A, M. (2017). Pengembangan Bahan Belajar Interaktif Berkonten Lokal Wisdom Dengan Format .Swf Untuk Pelajaran Matematika Sekolah Menengah. Universitas Pendidikan Indonesia.
Kurniati, A., Tanzil, F., \& Purnomo, F. (2015). Game Development “ Tales of Mamochi " With Role Playing Game Concept Based on Android. Procedia - Procedia Computer Science, 59, 392-399.

Kusmanto, H., \& Marliyana, I. (2014). Pengaruh Pemahaman Matematika Terhadap Kemampuan Koneksi Matematika Siswa Kelas VII Semester Genap SMP Negeri 2 Kasokandel Kabupaten Majalengka. Jurnal Eduma, 3(2), 61-75.

Naila, R., Tasya, N., Rahayu, E. S., Hidayat, W. (2018). Analisis Kesalahan Operasi Hitung Siswa Smk Pada Materi Matriks Dengan Pedekatan Pembelajaran Problem Based Learning. Jurnal Pendidikan Tambusai, 2, 18511853.

Nurafni, A., Pujiastuti, H., \& Mutaqin, A. (2020). Pengembangan Bahan Ajar Trigonometri Berbasis Kearifan Lokal. Journal of Mathematics Education IKIP Veteran Semarang. 4(1), 73.

Panggayudi, D.S \& Suweleh, W. P. I. (2017). Media Game Edukasi Berbasis Budaya Untuk Pembelajaran Pengenalan Bilangan Pada Anak Usia Dini. Journal of Mathematics Education, Science and Technology, 2(2), 255-266.

Pramuditya, S. A., \& Noto, M. S. (2018). Desain Game Edukasi Berbasis Android pada Materi Logika Matematika. JNPM (Jurnal Nasional Pendidikan Matematika), 2(2), 165-179.

Sari, K. W., Saputro, S., \& Hastuti, D. B. (2014). Pengembangan Game Edukasi Kimia Berbasis Role Playing Game (RPG) pada Materi 
Struktur Atom sebagai Media Pembelajaran Mandiri untuk Siswa Kelas X Sma di Kabupaten Purworejo. Jurnal Pendidikan Kimia (JPK).

Schilling, K. (2009). The impact of multimedia course enhancements on student learning outcomes. Journal of Education for Library and information Science, 50(4), 214-225.

Tegeh, M., Jampel, N., \& Pudjawan, K. (2014). Model Penelitian Pengembangan. Yogyakarta: Graha Ilmu.
Wicaksono, D. P., Kusmayadi, T. A., \& Usodo, B.. (2014). Pengembangan Perangkat Pembelajaran Matematika Berbahasa Inggris Berdasakan Teori Kecerdasan Majemuk (Multiple Intelligences) pada Materi Balok dan Kubus untuk Kelas VIII SMP. Jurnal Elektronik Pembelajaran Matematika. 2:5. 538

Widoyoko, S. Eko Putro. (2009). Evaluasi Program Pembelajaran. Yogyakarta ; Pustaka Belajar.

Yamasari, Y. (2010). Pengembangan Media Pembelajaran Matematika Berbasis ICT yang Berkualitas. Seminar Nasional Pascasarjana $X$-ITS 